\author{
Astrid Sinnes \\ Norges miljø- og biovitenskapelige universitet \\ Ingerid S. Straume \\ Universitetet i Oslo
}

DOI: http://dx.doi.org/10.5617/adno.4698

\title{
Bærekraftig utvikling, tverrfaglighet og dybdelæring: fra big ideas til store spørsmål
}

\section{Sammendrag}

I den norske stortingsmeldingen «Fag - Fordypning - Forståelse. En fornyelse av Kunnskapsløftet» er «bcerekraftig utvikling» ett av tre tverrfaglige temaer som skal gi retning til fornyelse av skolefagene. Sammenlignet med resten av Skandinavia har bærekraftig utvikling så langt hatt en mindre forpliktende stilling i norsk skole. Bakgrunnen for dette er sammensatt, og skyldes forhold både i og utenfor skolen. Spørsmålet som diskuteres her, er hvordan den nye satsningen på utdanning for bcrekraftig utvikling kan gi temaet en mer aktiv rolle i framtidens norske skole enn det vi har sett til nå. I den sammenheng ser vi spesielt på spenninger implisitt i begrepet bcerekraftig utvikling, forholdet mellom dybdelcering og tverrfaglighet, samt betydningen av handlinger og erfaringer som fremmer en bcerekraftig utvikling. Konklusjonen er at det er tvilsomt om fokusering på «big ideas» og kjerneelementer i fagene (stortingsmeldingens anbefalinger) i seg selv vil lede til den tverrfaglige, systemiske forståelsen og kompetansen som er nødvendig for å leve bcrekraftige liv i framtidens samfunn. Som alternativ tilncerming foreslår vi å ta utgangspunkt i tidens store spørsmål: det vi lurer på i dag.

Nøkkelord: utdanning for bærekraftig utvikling, dybdelæring, tverrfaglighet, lereplaner, Norge

\section{Sustainable development, interdisciplinarity and deep learning: from big ideas to big questions}

\begin{abstract}
The Norwegian White Paper "Fag - Fordypning - Forståelse. En fornyelse av Kunnskapsløftet" [Subjects - Immersion - Understanding. A Renewal of the Knowledge Promotion] states that sustainable development is to be one of three interdisciplinary themes that should guide and inform the renewal of subjects in Norwegian K12 education. Compared to the rest of Scandinavia, education for
\end{abstract}


sustainable development, ESD, has so far been relatively weakly implemented in the Norwegian school system. This is due to complex relations both in and outside of schools. The question discussed in this paper is whether the new initiative for sustainability promises a more effective implementation in the Norwegian "school of the future" than we have seen so far. We elucidate tensions implicit in the concept of sustainable development, the relationship between deep learning and interdisciplinarity, and the significance of actions and experiences that foster sustainable development. Our conclusion is that it is doubtful whether focusing on "big ideas" and core elements in the school subjects (as recommended in the White Paper), in itself will lead to the crossdisciplinary, systemic outlook and competency needed to lead sustainable lives in the future. As an alternative approach, we recommend starting with the big questions of our time: issues we wonder about today.

Keywords: education for sustainability, deep learning, interdisciplinarity, national curricula, Norway

\section{Innledning}

Regjeringen Solberg har bestemt at den norske skolen skal fornye sine læreplaner. I den forbindelse er det laget en offentlig utredning (NOU), en stortingsmelding og utkast til «Overordnet del - verdier og prinsipper for grunnopplæringen» (Kunnskapsdepartementet, 2017) som skal erstatte den generelle delen av læreplanverket fra 1997(KUF, 1996). Da Ludvigsenutvalget la fram sin utredning om hva slags fag og kompetanser som vil være viktige for framtidens skole, Fremtidens skole - Fornyelse av fag og kompetanser (NOU 2015: 8), var ett av forslagene å innføre tre gjennomgående «flerfaglige» temaer i læreplanverket. Ifølge stortingsmeldingen som fulgte, Fag - Fordypning - Forståelse. En fornyelse av Kunnskapsløftet, var høringssvarene positive til et slikt forslag: «Dels uttaler høringsinstansene at temaene som utvalget peker på, generelt er viktige, og dels at det er en styrke når opplæringen kobler innhold i ulike fag til overordnede problemstillinger og temaer» (Kunnskapsdepartementet, 2016, s. 38). Departementet valgte da også å støtte forslaget, men med noen endringer, blant annet ved å kalle temaene «tverrfaglige» og omformulere to av dem slik at temaene blir «demokrati og medborgerskap», «bærekraftig utvikling» og «folkehelse og livsmestring».

Innføringen av temaer kan i en viss forstand ses som en vending bort fra læreplanen for Kunnskapsløftet fra 2006, der myndighetene verken ønsket å legge føringer for skolens innholdsmessige prioriteringer eller for arbeidsmåter, men heller formulerte krav til vurderingsformer, styring og planarbeid. L97s sterke vektlegging av prosjekt- og temaarbeid ble dermed i stor grad - om enn ikke nødvendigvis tilsiktet - fortrengt av et regime som har vært karakterisert 
som målings- og testdrevet (Malkenes, 2014; Sinnes \& Eriksen, 2015; Sjøberg, 2015). I et slikt perspektiv blir de økte mulighetene for igjen å jobbe tema- og prosjektbasert trolig en velkommen anledning for mange, ikke minst for lærere. Spørsmålet som skal diskuteres her, er om de nye læreplanene vil gi tilstrekkelig rom for å jobbe tverrfaglig og «dypt» med de store problemstillingene knyttet til bærekraftig utvikling og de andre temaene, og hva som skal til for at den nye satsningen kan bidra til en virkelig framtidsrettet pedagogikk og didaktikk. Utdanning for bærekraftig utvikling (engelsk: education for sustainable development) er et stort, internasjonalt fagfelt, der stikkord er systemisk forståelse, transformative læringsprosesser og overskridelse av hittil atskilte fagtradisjoner og perspektiver (Sinnes, 2015; Sterling, 2009; Wals, 2012). Med dette som utgangspunkt vil vi ta for oss noen av de spenningene som preger feltet i norsk sammenheng, og antyde en retning for det videre arbeidet med fornyelse av fag og læreplaner som etter vårt syn vil bidra til den kompetansen som er nødvendig i et samfunn som vil preges av store endringer, enten vi vil eller ei (O’Brien \& Selboe, 2015).

Når det gjelder de tre temaene, kan det imidlertid være problematisk å skille dem på en meningsfull måte. Dette gjelder spesielt for «bærekraftig utvikling», som nettopp dreier seg om å skape sammenheng mellom det som angår personlige forhold (livsmestring), politisk-samfunnsmessige prosesser (demokrati og medborgerskap) og hensynet til natur og kommende generasjoner (se for eksempel Brundtlandrapporten Vår felles framtid (Verdenskommisjonen for miljø og utvikling, 1987)). En tendens fra tidligere satsninger på bærekraftig utvikling i norsk skole er at temaet hovedsakelig blir overlatt til naturfagene (Andresen, Høgmo \& Sandås, 2015; Straume, 2016). Denne slagsiden mot natur- og miljøfag er en av de største utfordringene i feltet slik vi ser det - en utfordring som ser ut til å være bedre ivaretatt i våre naboland Sverige og Danmark, som har sterkere forskningstradisjoner når det gjelder utdanning for bærekraftig utvikling. Vårt utgangspunkt er at bærekraftig utvikling nettopp må forstås som et tema på tvers av alle fag, og ikke delegeres til naturfagene, slik tendensen har vært i tidligere satsninger. ${ }^{1}$ Likeledes kan temaet «demokrati og medborgerskap» ikke reserveres for samfunnsfagene alene, eller «folkehelse og livsmestring» for fagene kroppsøving og mat og helse. Alle de tre temaene kan dermed, i et større perspektiv, betraktes som uttrykk for visjonen om en mer bærekraftig utvikling som til dels preger Ludvigsenutvalgets, og i noe mindre grad stortingsmeldingens ideer for framtidens skole.

Definisjonen av bærekraftig utvikling fra Brundtlandrapporten: «en utvikling som ivaretar dagens behov uten å ødelegge mulighetene for at kommende generasjoner skal få dekket sine behov» (Verdenskommisjonen for miljø og utvikling, 1987, s. 42), viser nettopp at politiske, sosiale, økonomiske og miljømessige forhold er tett sammenvevd. For eksempel kan man ikke ha en bærekraftig utvikling bare for en liten del av verdens beboere; det er jordens ulike systemer som må være bærekraftige dersom man skal ivareta kommende generasjoners 
muligheter til å utvikle seg. Dette innebærer at de samfunnsmessige (samfunnsfaglige) utfordringene er minst like store som de naturfaglige.

Stortingsmeldingens utsagn om bærekraftig utvikling, som tar utgangspunkt i denne forståelsen, er kort nok til å gjengis i sin helhet:

Bærekraftig utvikling skal også bli et prioritert tema i læreplanverket. Opplæringen i dette tverrfaglige temaet skal i tråd med formålsparagrafen bidra til at elevene lærer å tenke kritisk og handle etisk og miljøbevisst. Bærekraftig utvikling handler om å ta vare på behovene til mennesker som lever i dag, uten å ødelegge fremtidige generasjoners muligheter til å dekke sine. Skal det lykkes, må det tenkes og handles lokalt, nasjonalt og globalt. Ifølge $\mathrm{FN}$ vil det å forbedre sosiale forhold, miljøproblemer og økonomisk ulikhet i verden være viktige bidrag til en bærekraftig utvikling. De tre dimensjonene sosiale, miljømessige og økonomiske forhold henger sammen og gir gode muligheter til å behandle temaet tverrfaglig i skolen. Ulike fag vil bidra til at elevene utvikler kunnskap om de tre dimensjonene og får grunnlag for å forstå sammenhengen mellom dem. Ny teknologi og teknologisk utvikling skal, i tillegg til etisk refleksjon og dømmekraft knyttet til teknologiutviklingen, være sentrale innenfor det tverrfaglige temaet bærekraftig utvikling. (Kunnskapsdepartementet, 2016, s. 39)

Den første halvdelen av avsnittet bygger på essensen fra Brundtlandrapporten og oppfølgingen i FN-systemet under merkelappen Education for Sustainable Development (ESD, eller på norsk: UBU). Nest siste setning (ulike fag vil bidra til ... å forstå sammenhengen ...) knytter på sin side an til en tenkt sammenheng mellom dybdelæring og tverrfaglighet fra Ludvigsenutvalgets utredning (NOU 2015: 8), som belyses lenger ned. Den siste setningen, med sin skal-formulering om ny teknologi, der etisk refleksjon og dømmekraft er formulert som et tillegg, har en litt annen språklig karakter enn de øvrige. Setningen er normativt formulert, og virker innskutt. Imidlertid kan det argumenteres for at nettopp denne setningen gjenspeiler noen av de grunnleggende spenningene som ligger i feltet selv, slik vi skal utdype og diskutere lenger ned.

«Overordnet del - verdier og prinsipper for grunnopplæringen» (Kunnskapsdepartementet, 2017) inneholder både snevre og mer nyanserte utsagn om bærekraftig utvikling i skolen. Avsnitt 2.6.3 med tittelen «Bærekraftig utvikling» tilhører sistnevnte kategori; her understrekes det at teknologiutvikling ikke bare kan bidra til å løse en rekke problemer, men også skape nye. «Kunnskap om teknologi», hevdes det under avsnittet «bærekraftig utvikling», «innebærer en forståelse av hvilke dilemmaer som kan oppstå ved bruk av teknologi, og hvordan disse kan håndteres» (s. 14). En slik kompleks, nyansert forståelse kan neppe oppnås uten å aktivisere hele skolens forståelsesrepertoar, det vil si alt fra det naturfaglige, teknologiske og praktiske til de mer forståelsesorienterte fagene med humanistiske og samfunnskritiske dimensjoner.

Når bærekraftig utvikling skal innarbeides som et tverrfaglig tema i de ulike fagene, er det også viktig å kjenne til hvilken plass det har hatt tidligere. Formuleringen i stortingsmeldingen som sier at bærekraftig utvikling «skal bli et prioritert tema i læreplanverket», kan gi inntrykk av at dette ikke har vært 
prioritert i tidligere læreplaner. Selv om bærekraftig utvikling langt fra har fătt den gjennomslagskraften det fortjener i den norske skolen, har dette temaet likevel vært til stede i norsk utdanningspolitikk siden begynnelsen av 1970tallet. Vi vil derfor kort ta for oss begrepet bærekraftig utvikling og dets rolle i tidligere læreplaner. Deretter ser vi på hvilken plass bærekraftig utvikling har i skolens nåværende praksis. Vi vil så diskutere hvilke mulige spenninger som ligger i grunnlagsdokumentene for arbeidet med de nye planene, før vi avslutter med noen forslag som kan styrke dette feltets gjennomslagskraft i det nye læreplanverket.

\section{Natur, miljø og bærekraftig utvikling i norsk skole}

Skolens læreplaner kan sies å speile offentlighetens ulike oppfatninger av naturog miljøspørsmål gjennom historien. I korte trekk kan vi snakke om tre hovedfaser: først det tradisjonelle naturvernet, som dreier seg om å bevare og forvalte naturen; dernest natur- og miljøvern (fra ca. 1970), der nye problemer knyttet til miljøgifter, ressursmangel og forurensning kom på dagsorden, og dernest ideen om bærekraftig utvikling som ble innført med Verdenskommisjonen for miljø og utvikling (Brundtlandkommisjonen) i 1987. Dagens klimaproblemer representerer ytterligere en utfordring for kunnskaps- og opplæringsspørsmål som også danner et bakteppe for Ludvigsenutvalget, men her velger vi å ta for oss bærekraftig utvikling mer allment. ${ }^{2}$ De ulike forståelsene av feltet rommer ulike oppfatninger om samfunnsforhold, om menneskets forhold til naturen og om naturen selv. Det er dermed ikke overraskende at det finnes spenninger - også politiske spenninger - i dette fagfeltet.

Den første norske læreplanen som gjorde natur- og miljøvern til obligatorisk tema, var Mønsterplanen av 1974 (M74). Undervisningen skulle hovedsakelig skje i naturfag, men også samfunnsfag, kristendom og heimkunnskap er nevnt i emneplanen. Det overordna målet for emnet var formulert slik:

Skolen må gjennom sin undervisning gi elevene forståelse for naturens betydning for vårt [sic] liv, ikke bare økonomisk, men også som kilde til rekreasjon og som inspirasjon i forskning og undervisning. De farer som truer vårt livsmiljø gjennom hensynsløs utnytting av naturressursene, og ved forurensing av jord, vann og luft må klarlegges for elevene slik at de vekkes til ansvar for å hindre ødelegging av naturverdier, og dessuten anspores til å gjøre en aktiv innsats for å bevare verdiene for kommende slekter. (Kirke- og undervisningsdepartementet, 1974, s. 277)

M74 hadde, i likhet med det den ferske stortingsmeldingen legger opp til, definert 11 fagovergripende «obligatoriske emner» som spesifiserte ulike temaer som skulle behandles i flere fag. I beskrivelsen av natur- og miljøvern står det (ikke ulikt dagens føringer) at: «i skolen må ikke naturvern bli et isolert emne som gjøres til gjenstand for behandling bare i begrensede perioder og bare i 
enkelte fag. Naturvernsynspunkter bør komme inn i biologiundervisningen gjennom alle år og over alt hvor det er naturlig» (Kirke- og undervisningsdepartementet, 1974, s. 277).

I løpet av 1970- og 80-tallet ble den vestlige verden oppmerksom på en del nye problemer knyttet til industrialisering, som forurensning, ressursknapphet og radioaktivitet. Man ble med andre ord opptatt av større sammenhenger, økologiske så vel som politiske, noe som var bakgrunnen for at naturvern ble til miljøvern (Jansen, 1989; Sandås \& Isnes, 2015). Mønsterplanen fra 1987 (M87) la noe mer vekt på de samfunnsmessige og økonomiske sidene av miljøtematikken, og var dermed mer tverrfaglig innrettet enn planen fra 1974.

I 1994 ble det satt ned et utvalg, populært kalt Sjøbergutvalget (KUF, 1994), som skulle gjennomgå læreplanen spesielt med tanke på naturfagenes stilling i skolen. Etter en knusende dom over datidens O-fag (orienteringsfag, som skulle integrere lærestoff fra naturfag og samfunnsfag) for ikke å legge vekt på realfagene, ble O-faget endret til natur- og miljøfag i læreplanen som ble innført i $1997 .^{3}$ Her var samfunnsfag blitt et eget fag på mellomtrinnet, og naturfaget var gjort mer naturvitenskapelig, men fortsatt knyttet til miljøspørsmål. I 2006 fikk Norge igjen nye lærerplaner. I Læreplanen for Kunnskapsløftet var naturog miljøfag blitt til bare naturfag. Selv om «miljø» nå var tatt ut av tittelen på faget, var hoveddelen av undervisningen i miljøspørsmål lagt til naturfag i både L97 og Kunnskapsløftet. Miljøaspektet var også med i fagene samfunnsfag, mat og helse, $\mathrm{KRLE}^{4}$ og kunst og håndverk, om enn i mindre skala.

Den gjeldende Læreplanen for Kunnskapsløftet består av tre deler: prinsipper for opplæringen, generell del av læreplanen og kompetansemål for fagene. Flere av prinsippene for opplæringen har mye til felles med den internasjonale litteraturen om utdanning for bærekraftig utvikling, for eksempel arbeidsformer som aktiviserer elevene og utfordrer deres fantasi og skaperevne; tverrfaglig samarbeid og helhetlig kunnskap; bruk av lokalsamfunnet som undervisningsarena; vektlegging av etiske problemstillinger; og vurderingsformer som tar hensyn til et utvidet kunnskapsbegrep. Den generelle delen av læreplanen (som nå skal erstattes) beskriver syv sider ved mennesket som skal utdannes gjennom den norske skolen: det meningssøkende, skapende, arbeidende, allmenndannende, samarbeidende, integrerte og miljøbevisste mennesket. I beskrivelsen av det miljøbevisste mennesket står det:

Vårt levesett og vår samfunnsform har dype og truende virkninger for miljøet. Dette driver fram konflikter mellom grupper og mellom land. Konsekvensene av vitenskapens anvendelse er på en gang blitt mer omfattende og sammenflettede. Dette gjør det nødvendig å utvide innsikten om sammenhenger på tvers av faggrenser, og å mobilisere til innsats på tvers av landegrenser. Det øker kravene både til viten og til bevisste økologiske, etiske og politiske avgjørelser hos enkeltindivider og samfunn. Forståelse gjør at valg kan treffes med innsikt, etisk fostring at de kan tas med skjønn. De utviklede land med høyt utdanningsnivå har et særlig ansvar for å sikre verdens felles framtid. (Utdanningsdirektoratet, 2011, s. 20-21) 
Igjen ser vi argumentet om at tidens problemer krever tverrfaglig forståelse. Når det gjelder temaer knyttet til bærekraftig utvikling, finnes det flere slike i «Kompetansemål for fag» i samfunnsfag og naturfag (og noe i mat og helse, KRLE og kunst og håndverk). Bærekraftig utvikling er i tillegg et eget hovedområde på videregående trinn i naturfag.

\section{UBU-prosjekter i den norske skolen}

En god sjanse til å forsterke arbeidet med bærekraftig utvikling i den norske skolen kom da FN, gjennom UNESCO, viet et helt tiår til Utdanning for bærekraftig utvikling (Decade for Education for Sustainable Development, DESD). Da tiåret for Utdanning for bærekraftig utvikling ble lansert i mars 2005, sa daværende leder av den norske UNESCO-kommisjonen Astrid Nøklebye Heiberg at kunnskap om bærekraftig utvikling skal gjennomsyre all undervisning i den norske skole.

Det nasjonale senteret for naturfag i opplæringen (Naturfagsenteret) har fått hovedansvaret for å følge opp UBU-satsningen i Norge. Det har i all hovedsak vært gjort gjennom utvikling og administrasjon av programmet «Den naturlige skolesekken» (DNS). DNS er, ifølge nettsiden natursekken.no «en nasjonal skolesatsning som skal bidra til at barn og unge gjennom opplæringen får kunnskap om og blir bevisste på bærekraftig utvikling og klodens miljøutfordringer». Den naturlige skolesekken bidrar med midler til kompetanseheving for lærere og utvikling av undervisningsopplegg for bærekraftig utvikling. I 2014 gjennomførte Nordisk institutt for studier av innovasjon, forskning og utdanning, NIFU, en evaluering av DNS på oppdrag av Utdanningsdirektoratet. I denne evalueringen står det at 602 prosjekttildelinger var blitt gitt gjennom DNS fra prosjektstart. Dette er dermed den største enkeltsatsningen på utdanning for bærekraftig utvikling i den norske skolen (Sjaastad, Carlsten, Opheim \& Jensen, 2014). Et annet stort skoleprosjekt, som lenge har hatt en plass i den norske skolen, er Miljølære, miljolare.no. Dette nettstedet, som tilsvarer det engelskspråklige nettstedet SUSTAIN.no, er en plattform hvor skoleelever kan samle inn og registrere miljødata som igjen kan anvendes av kommuner i planlegging. I tillegg har blant andre FN-sambandet, UNESCO og Naturvernforbundet egne prosjekter rettet mot skolens arbeid med bærekraftig utvikling. Skolene har også anledning til å være med på praktisk miljøarbeid gjennom sertifiseringsordninger som Grønt flagg. Sammen med læreplanene utgjør disse eksterne initiativene rike muligheter for lærere til å arbeide med bærekraftig utvikling i skolen. Vi vil nå se mer på hvordan disse initiativene kommer til uttrykk, og i hvilken grad skolen gjennomsyres av ideen om bærekraftig utvikling slik intensjonen med FNs tiår for utdanning for bærekraftig utvikling var. 


\section{Hvordan er UBU praktisert i skolen?}

Det finnes så langt ingen store studier av hvordan bærekraftig utvikling praktiseres i den norske skolen. For å få en oversikt over dette har vi måttet gå til flere masteroppgaver som har studert skolenes oppfølging av UBU-satsninger, blant annet FN-tiåret (Brænden, 2008; Koller, 2009; Laumann, 2007; Raabs, 2010; Sundstrøm, 2016; Wolla, 2015). Vi har i tillegg studert resultatene fra NIFUs spørsmål til skoleledere i 2011 (NIFU, 2012), evalueringen av FNs tiår for utdanning for bærekraftig utvikling i Norge (Andresen et al., 2015) samt evalueringen som ble gjort av Den naturlige skolesekken i 2014 (Sjaastad et al., 2014). På bakgrunn av denne gjennomgangen vil vi trekke fram spesielt tre faktorer som er nokså entydige i dette materialet:

\section{Fragmentert satsning: Få skoler jobber helhetlig med UBU}

Bærekraftig utvikling dreier seg per definisjon om å legge om fra en utvikling som ikke er bærekraftig til noe som ennå ikke eksisterer, altså en transformasjon. Mye forskning på UBU peker på at ideen om bærekraftig utvikling må gjennomsyre hele skoler for å ha en transformativ effekt (Gadotti, 2010; Scott, 2013; Sterling, 2009). Både masteroppgavene og evalueringen av Den naturlige skolesekken påpeker at satsningen på bærekraftig utvikling i den norske skolen er fragmentert og lite helhetlig. Den naturlige skolesekken har stort sett gitt støtte til enkeltlærere, ikke til hele skoler, og selv om disse har jobbet med tverrfaglige initiativer, har dette i liten grad ført til strukturelle endringer i skolene. Det finnes svært få eksempler på skoler som har bærekraftig utvikling som et helhetlig fokus for sin undervisning (Andresen et al., 2015; Laumann, 2007; Raabs, 2010; Sjaastad et al., 2014; Sundstrøm, 2016).

\section{UBU oppleves som lite forpliktende}

I en studie av hvordan naturfag- og samfunnsfaglærere i enkelte ungdomsskoler i Oslo arbeidet med bærekraftig utvikling, fant Marianne Brænden (2008) at temaer knyttet til bærekraftig utvikling ofte falt mellom flere stoler. Mens naturfaglærerne mente at dette var tema som hørte til i samfunnsfag, hevdet samfunnsfaglærerne at dette hørte hjemme i naturfagundervisningen (Brænden, 2008). Likeledes fant Elina Sundstrøm (2016) i sin studie av naturfaglærere i de tre nordligste fylkene i Norge at de oppfattet bærekraftig utvikling som et tema som epistemologisk ikke hørte hjemme i naturfagene, da disse temaene ble sett på som politiske:

Studien viser at emnet BU tilsynelatende blir nedprioritert blant mange lærere, og at lærerne ikke anser BU til å verken 'gjennomsyre' skolens virksomhet eller skolekultur. Temaets plassering bakerst i læreverkene og på slutten av undervisningsåret gjør at BU virker å fremstå som et 'vedheng' i naturfaget som lett kan nedprioriteres, særlig dersom tiden er knapp. (Sundstrøm, 2016, s. 65) 
Lærere fra videregående skole som deltok i Kollers studie (2009), oppfattet arbeidet med bærekraftig utvikling som lite forpliktende; temaet kom ofte sist i lærebøkene, og noen av lærerne hun intervjuet kalte dette for «trøste og bærekapitlet». Likeledes fant Sinnes og Jegstad (2011), som intervjuet to tidligere masterstudenter ved NMBU, at de som nyutdannete lærere opplevde liten interesse for bærekraftig utvikling ved sine arbeidsplasser i videregående skole. Dels var det liten oppmerksomhet omkring den generelle delen av lærerplanen og forpliktelsen til å utdanne miljøbevisste mennesker, dels var det lite engasjement blant kollegene for å drive tverrfaglig arbeid, noe som gjerne blir sett på som en forutsetning for å få til god, helhetlig utdanning for bærekraftig utvikling, ifølge UNESCO (2006).

En gjennomgang av læreplanen for Kunnskapsløftet i forbindelse med utarbeiding av den norske strategien for å følge opp FNs tiår for utdanning, viste at denne i liten grad legger opp til en helhetlig og forpliktende undervisning for bærekraftig utvikling (Naturfagsenteret, 2010). Kunnskapsløftet legger ifølge rapporten vekt på å fremme en teoretisk undervisning om bærekraftig utvikling, men det er lite rom for at elevene får erfare og utvikle arbeidsmåter som fremmer bærekraftig utvikling i praksis. Det er altså en interesse for å fremme elevenes teoretiske kunnskap om hva som kjennetegner en bærekraftig utvikling heller enn å utvikle deres handlingskompetanse og praktiske ferdigheter for å kunne bidra til at utviklingen faktisk blir mer bærekraftig (Naturfagsenteret, 2010; se også Laumann, 2007). Inntrykket av at bærekraftig utvikling er lite forpliktende i den norske skolen, støttes også i evalueringen av implementeringen av FNs tiår for utdanning for bærekraftig utvikling i Norge (Andresen et al., 2015). Et viktig unntak her er Steinerskolene, der bærekraftighet, i vid forstand, er et gjennomgående perspektiv i læreplan, undervisning, forvaltning, skolebygg mv. ${ }^{5}$

\section{UBU i Norge er svært læreravhengig}

Ettersom satsningen på bærekraftig utvikling i den norske skolen så langt har vært lite forpliktende, blir det opp til den enkelte lærer hvorvidt dette temaet løftes fram og tas videre (Laumann, 2007; Brænden, 2008; Koller, 2009; Raabs, 2010; Sinnes \& Jegstad, 2011; Sjaastad et al., 2014; Sundstrøm, 2016). Dette aktualiserer selvsagt også spørsmålet om hvilken kompetanse lærerne får gjennom sin utdanning - et spørsmål som vi ikke kan gå inn på her. Men som Kari Laumann skriver, er det mange lærere som er interessert i temaet:

Mange lærere er engasjerte, interesserte og arbeider hardt for å gjøre bærekraftig utvikling til et relevant og attraktivt emne for elevene. Bærekraftig utvikling er imidlertid bare ett av mange emner som krever oppmerksomhet fra elever og lærere. På grunn av mangelen på systematisk inkludering i lærerplaner og lærerbøker, og mangelen på kompetanse blant lærerne, blir emnet i mange tilfeller lavt prioritert. Hvorvidt tema relatert til bærekraftig utvikling blir undervist, og hvordan disse 
temaene blir undervist, avhenger mye av den enkelte lærer. (Laumann, 2007, s. 102, vår oversettelse)

Det finnes, som vist i gjennomgangen av norske læreplaner, muligheter (og også krav til) å arbeide med bærekraftig utvikling i skolen, men mangelen på forventninger bidrar likevel til at det kreves et personlig engasjement for å ta det opp i undervisningen. Elina Sundstrøm konkluderer i sin oppgave:

Som det fremgår i studien kan det se ut som om visjonen om UBU i den videregående skolen ikke vektlegges som tiltenkt av LK06 og de norske strategiplanene. Studien indikerer at lærerne anser UBU som interessant og viktig, men at det ikke er gjennomførbart med dagens rammebetingelser. Flere kjente utfordringer knyttet til UBU fremheves i studien, blant annet manglende helhetlig satsning og tidspress i faget, som bidrar til at emnet nedprioriteres blant mange naturfagslærere. [...] Lærerne uttrykker også ønske om kompetanseheving, både faglig og didaktisk. (Sundstrøm, 2016, s. 2)

Det er så langt vi kjenner til ikke gjort noen undersøkelser på hvilke faktorer som ligger til grunn for at enkelte lærere involverer seg i eksterne UBUprosjekter slik som DNS, Miljølære, FN-sambandet osv., men vi vil tro at dette er lærere som i utgangspunktet er opptatt av spørsmål knyttet til miljø og bærekraft. Ifølge undersøkelser som er gjort i skolen, gir imidlertid flere lærere utrykk for at det er vanskelig å jobbe tverrfaglig (Brænden, 2008; Koller, 2009; Sinnes \& Jegstad, 2011; Sundstrøm, 2016). Friheten til å velge undervisningsmetoder som ble innført gjennom Kunnskapsløftet, gjør det lettere for lærere å droppe metoder som er sentrale i UBU, for eksempel uteundervisning (Koller, 2009; Sinnes \& Jegstad, 2011). Den norske strategien for oppfølgingen av FNs tiår for utdanning for bærekraftig utvikling peker også på at lærere behøver videreutdanning for å kunne arbeide med bærekraftig utvikling i skolen (Kunnskapsdepartementet, 2012). Så langt finnes det få tilbud om slik videreutdanning, med noen unntak. Lærerutdanningen ved Norges miljø- og biovitenskapelige universitet, NMBU, har i en årrekke hatt som overordnet mål å utdanne lærere som kan bidra til en bærekraftig utvikling, og Universitetet i Oslo har nylig også gjort dette til en satsning for lærerutdanningen. Det kan synes som om det - i likhet med i skolen - finnes muligheter for å arbeide med bærekraftig utvikling innenfor lærerutdanningen, men så lenge dette ikke er nedfelt som et mål i forskrifter og rammeplaner, blir det opp til den enkelte lærerutdanner å ta et aktivt valg for å prioritere dette.

\section{Skolens nye styringsdokumenter: spenninger og muligheter}

Som denne gjennomgangen viser, har målet om å la bærekraftig utvikling gjennomsyret arbeidet i skolen, formulert i en rekke styringsdokumenter, ikke ført til de endringene i skolens praksis som dagens miljøutfordringer skulle tilsi. 
Spørsmålet blir nå om fornyelsen av Kunnskapsløftet, som pågår i disse dager, blir den lenge etterlengtede anledningen til at Norge kan følge etter sine naboland i dette viktige arbeidet. ${ }^{6}$ Hvis så skal skje, er det etter vårt syn helt avgjørende å erkjenne at business as usual vil være utfallet med mindre det gjøres en aktiv innsats for det motsatte. For eksempel er det ingen automatikk i at dybdelæring i fagene skal føre til kreativitet og tverrfaglig forståelse, slik det forutsettes i Ludvigsenutvalgets rapport og stortingsmeldingen. Dette momentet utdypes lenger ned. Men det er også viktig å erkjenne at selve temaet (og fagfeltet) har noen innebygde spenninger som har gjort det mulig å definere bærekraftig utvikling på svært ulike, ja, motstridende måter (se for eksempel Lafferty \& Langhelle, 1995; Straume, 2005; Sæther, 2017). I Routledge Handbook of Higher Education for Sustainable Development hevdes det at: "What is unique about Education for Sustainable Development (ESD) is that it seems to embrace a whole range of competing worldviews. This is both a strength and a weakness of ESD» (Mochizuki \& Yarime, 2016, s. 11). Meld. St. nr. 28 (2015-2016), Fag - Fordypning - Forståelse. En fornyelse av Kunnskapsløftet, bygger på Brundtlandkommisjonen i sin definisjon av bærekraftig utvikling: «Bærekraftig utvikling handler om å ta vare på behovene til mennesker som lever i dag, uten å ødelegge fremtidige generasjoners muligheter til å dekke sine» (Kunnskapsdepartementet, 2016, s. 39). Denne definisjonen har, siden den ble lansert i 1987, høstet mye kritikk (se for eksempel Dobson, 1996). Utviklingsaspektet i definisjonen har vært kritisert for å fremme prinsippet om økonomisk vekst, noe mange hevder er uforenelig med ideen om en bærekraftig verden. Sentrale forskere innen UBU har derfor gått vekk fra å bruke begrepet «education for sustainable development» og bruker heller «sustainability education» eller «education for sustainability» (for eksempel Sterling, 2009).

Begrepet bærekraftig utvikling kan altså ikke bare ha mange ulike betydninger, men også innbefatte flere ulike verdenssyn som står i innbyrdes motsetning. Sinnes (2015) skiller mellom et teknooptimistisk verdenssyn hvor bærekraftsutfordringene stort sett anses å kunne løses med utvikling av en mer «bærekraftig» teknologi, og et økosentrisk syn på bærekraft, der mennesket blir sett på som en del av naturen og hvor det dermed også forventes en større grad av endring på et personlig nivå. Det er ikke vanskelig å forstå at disse posisjonene vil kunne føre med seg ganske ulike prioriteringer til en «utdanning for bærekraftig utvikling». Det er derfor av avgjørende betydning å analysere formuleringene i Meld. St. 28 (2015-2016) og andre styrende dokumenter for å avdekke hvilke perspektiver det legges opp til.

I avsnittet som beskriver bærekraftig utvikling i stortingsmeldingen står det som nevnt at: «Ny teknologi og teknologisk utvikling skal, i tillegg til etisk refleksjon og dømmekraft knyttet til teknologiutviklingen, være sentrale innenfor det tverrfaglige temaet bærekraftig utvikling» (Kunnskapsdepartementet, 2016, s. 39, vår utheving). Også i ny «Overordnet del - verdier og 
prinsipper for grunnopplæringen» (Kunnskapsdepartementet, 2017) trekkes teknologi frem som en sentral del under temaet bærekraftig utvikling: «Teknologisk kompetanse og kunnskap om sammenhengene mellom teknologi og de sosiale, økonomiske og miljømessige sidene ved bærekraftig utvikling står derfor sentralt i dette temaet» (s 14). At bærekraftig utvikling i så stor grad knyttes opp mot teknologi og teknologiutvikling, kan etter vårt syn tyde på at regjeringen legger et teknooptimistisk bærekraftsperspektiv til grunn, der teknologi og teknologiutvikling anses som «løsningen» på bærekraftsutfordringene. Et slikt perspektiv vil kunne stå i spenning til et mer økosentrisk perspektiv der mennesket ikke bare sees på som en del av problemet, men det enkelte individ også får en større rolle som en del av selve løsningen(e), utover å finne opp ny teknologi. Et slikt perspektiv åpner også opp for å arbeide med de samfunnsmessige og kulturelle aspektene ved utviklingen, der det etter manges mening ligger sentrale årsaker til at den nåværende utviklingen ikke er bærekraftig (O’Brien \& Selboe, 2015; Sterling, 2009). Sagt på en annen måte: selv om teknologisk utvikling er svært viktig for dagens industrialiserte samfunn, kan det være mer grunnleggende trekk ved måten vi organiserer oss som samfunn som må endres i framtiden, og skolen - i sin fulle bredde, faglig og sosiokulturelt - vil være en sentral del av dette. Overordnet del - verdier og prinsipper for grunnopplæringen (Kunnskapsdepartementet, 2017, s. 14) viser til at dette feltet er preget av dilemmaer, kompleksitet og usikkerhet, kommer man inn på spørsmål som angår selve måten samfunnet forstår seg selv på, det vil i dypeste forstand si spørsmål om mening. Disse formuleringene er etter vårt syn noen av de viktigste i forarbeidene til fornyelse av læreplanene.

\section{Dybde og tverrfaglighet - fra fag til forståelse?}

Et av de sentrale bidragene fra Ludvigsenutvalget til stortingsmeldingen dreier seg om dybdelæring. Dybdelæring, ifølge stortingsmeldingen, «betyr at elevene gradvis og over tid utvikler sin forståelse av begreper og sammenhenger innenfor et fag». Dette står i kontrast til overflatelæring, «som legger vekt på innlæring av faktakunnskap uten at kunnskapen settes i sammenheng». Poenget er at «[e]levenes læringsutbytte øker når de gjennom dybdelæring utvikler en helhetlig forståelse av fag og ser sammenhengen mellom fag, samt greier å anvende det de har lært, til å løse problemer og oppgaver i nye sammenhenger» (Kunnskapsdepartementet, 2016, s. 14). Der overflatelæring preges av formidlingspedagogikk og gjengivelse av fakta uten dypere forståelse av mening og sammenheng, skal dybdelæring i det enkelte fag også bidra til forståelse i flere fag, og på tvers av fag. Hvordan er dette tenkt å finne sted?

Et sentralt premiss i meldingen er at dybdelæring ikke bare dreier seg om faglige prinsipper, men like mye om å utvikle læringsstrategier, motivasjon, metakognisjon mv. Stortingsmeldingen omtaler dette som en «flerdimensjonal» 
forståelse av læring: «Det betyr at læring foregår i samspill mellom kognitive og sosiale og emosjonelle ferdigheter (skills) som for eksempel utholdenhet, evne til å arbeide målrettet og takle motgang, nysgjerrighet, kreativitet og samarbeidsevne» (Kunnskapsdepartementet, 2016, s. 14). Ludvigsenutvalget, som stortingsmeldingen bygger videre på, anfører at forståelse innenfor et fag - av begreper, prinsipper, metoder mv. - bidrar til mening og opplevelse av mestring, altså motivasjon (NOU 2015: 8, s. 11). Dybdelæring i fag vil i denne forståelsen også omfatte personlige egenskaper og det vi kan kalle danningsmål.

Det å beherske «sentrale elementer» i ett eller flere fag vil etter utvalgets mening også gjøre det lettere å «overføre læring fra ett fag til et annet» (NOU 2015: 8, s. 11). Det dreier seg om «elevenes gradvise utvikling av forståelse av begreper, begrepssystemer, metoder og sammenhenger innenfor et fagområde», men også om å «forstå temaer og problemstillinger som går på tvers av fag- eller kunnskapsområder. Dybdelæring innebærer at elevene bruker sin evne til å analysere, løse problemer og reflektere over egen læring til å konstruere en varig forståelse» (NOU 2015: 8, s. 14).

Det er imidlertid ikke slik at jo mer faglig dybde, jo mer overføringsverdi; snarere argumenterer utvalget for en avveining mellom dybde og bredde $\mathrm{i}$ ethvert fag: «Balansen mellom bredde og dybde er et av de dilemmaene som det er helt nødvendig at en fremtidig læreplanutvikling arbeider for å finne gode løsninger på». Men det kan likevel «ikke uten videre settes likhetstegn mellom bredde i fag og overflatisk læring i fag», fordi «[i]nnsikt i bredden på et kunnskapsområde kan være en forutsetning for elevenes forståelse og fordypning» (NOU 2015: 8, s. 39-40). En «bred forståelse» i fagene anses som viktig for elevenes kreative ferdigheter og for overføring av læring (Landfald, 2016, s. 91). ${ }^{7}$ Spørsmålet blir da hvor dypt det er mulig å gå i et fagområde og samtidig kunne se kunnskapen i en bredere sammenheng, og omvendt, hvor bredt innholdet kan gripe uten at elever mister dybdeforståelse (Landfald, 2016, s. 89). Dybdelæringen - i et passende balanseforhold med bredde - skal bidra til at kunnskap kan overføres og brukes i andre sammenhenger og på nye måter, det vil si til kreativitet (NOU 2015: 8, s. 49). I denne sammenheng kommer de tre temaområdene inn; utvalget anbefaler at læreplanen setter opp mål som går på tvers av flere fag (eller fagområder), fordi «[f]lerfaglig organisering av sentrale kompetanser kan være en måte å ivareta dybdelæring på i betydningen forståelse av sammenhenger» (NOU 2015: 8, s. 49). Eksemplet som nevnes, er klima, miljø og bærekraftig utvikling. Stortingsmeldingen hevder også at tverrfaglighet, «hvor elevene arbeider med problemstillinger eller temaer på tvers av fag, kan bidra til bedre sammenheng i læreplanverket» (Kunnskapsdepartementet, 2016, s. 24). I disse utsagnene blir det etter vårt syn tydelig at de tverrfaglige temaene mest av alt er en måte å skape mening og motivasjon $i$ fagene. Avveiningen mellom bredde og dybde, der det ikke skal være for mye av det ene eller det andre, peker også mot at det er en spenning mellom disse. Hvordan kan det da hevdes at veien til tverrfaglighet går gjennom dybdelæring i enkeltfag? Dette er 
langt fra klart, og tydeliggjør at det er et stort arbeid som påhviler dem som skal lage ny læreplan.

\section{Fagene først?}

Arbeidet med fornyelse av Kunnskapsløftet starter, ifølge stortingsmeldingen, med å identifisere sentrale byggesteiner eller kjerneelementer i det enkelte fag, der «hvert enkelt skolefag gjennomgås med sikte på å definere fagets kjerneelementer eller kjernebegreper. Kjerneelementene i et fag er det elevene må lære for å kunne mestre og anvende faget, det mest betydningsfulle faglige innholdet elevene skal arbeide med i opplæringen» (Kunnskapsdepartementet, 2016, s. 34). ${ }^{8}$ I en presisering av disse elementene nevnes «sentrale begreper, metoder, tenkemåter, kunnskapsområder og uttrykksformer i faget» (s. 34). I et neste steg peker stortingsmeldingen på at ethvert fag har noe som kalles «bærende ideer», som det er sentralt å identifisere: «Internasjonalt er det eksempler på utredninger, forskning og læreplaner som beskriver et fags bærende ideer (big ideas) eller sentrale begreper (core concepts, key concepts)» (s. 34). Eksemplet som gis, er en oversikt over kjerneelementer i naturfag (s. 35).

Et spørsmål som da melder seg, er hvordan de bærende ideene forholder seg til de tverrfaglige temaene. I stortingsmeldingen står det at:

Å lære om et tema fra forskjellige faglige perspektiver og anvende kunnskaper og ferdigheter fra ulike fag skal gi bedre forståelse og kompetanse i det enkelte faget, og samtidig gi innsikt i hvordan fag belyser et tema på ulike måter. Dette kan gi både motivasjon og en bedre faglig forståelse. Det er imidlertid en forutsetning at de tverrfaglige temaene kun skal inngå i de fagene hvor de er en sentral del av det faglige innholdet. I fagfornyelsen skal de prioriteres fremfor andre tverrfaglige temaer, men de skal ikke fortrenge annet vesentlig faglig innhold. (Kunnskapsdepartementet, 2016, s. 38, vår utheving)

Fra dette punktet, om ikke før, blir det tydelig at fagene - og fagenes egenart kommer først, og at fagene ikke skal endres på noen vesentlig måte i møte med temaene. Det blir også tydelig at ikke alle fag skal befatte seg med utdanning for bærekraftig utvikling, men kun de der bærekraftig utvikling er «en sentral del av det faglige innholdet». Da er veien kort til å peke på naturfagene, og kanskje samfunnsfag - skjønt sistnevnte vil kanskje heller få tildelt «demokrati og medborgerskap» samt «folkehelse og livsmestring». Dette forholdet, sammen med stortingsmeldingens understrekning av at teknologi og teknologiutvikling «skal» være «sentrale» i arbeidet med bærekraftig utvikling, vil etter vår mening kunne legge opp til en kraftig reduksjonisme og en snever forståelse av problemfeltet. Ikke minst er det essensielt, i et land som har bygd opp en betydelig nasjonalformue gjennom utvinning av olje og gass, at vanskelige spørsmål om miljø og bærekraft settes i et størst mulig samfunnsmessig perspektiv slik det i alle fall delvis legges opp til i utkastet til overordnet del 
(Kunnskapsdepartementet, 2017). Som Ole Andreas Kvamme (2017) har understreket, er det i den forbindelse vesentlig å ikke overse de humanistiske fagenes bidrag, der temaene kan settes inn i en større sammenheng: kultur og mening (se også Straume, 2017).

I lys av det internasjonale fagfeltet utdanning for bærekraftig utvikling vil en reduksjonisme som den vi her antyder, være dypt problematisk. For det første ser vi at tverrfagligheten lett kan forhandles bort, og bare komme inn der det er naturlig for fagets egenart, slik det også var tilfelle under M74. Mange økopedagogiske tenkere betrakter grenser og skott mellom ulike fag som en hindring mot å legge om til en mer bærekraftig utvikling, der selve disiplinorienteringen knyttes til dypere, epistemologiske skiller mellom subjekt og objekt, indre og ytre, mennesket og naturen; skiller som det er nødvendig å overskride for å utvikle nye kunnskapsformer (se for eksempel Bowers, 1997; Kahn, 2010). Uansett hvordan man ser på denne argumentasjonen, er det mulig å være enig $i$ at mange av dagens problemer krever fagoverskridende tilnærminger. For det andre ser vi en fare for at bærekraftig utvikling, nok en gang, vil komme «naturlig» bare til naturfagene. Dette vil, som allerede nevnt, bety at viktige samfunnskritiske perspektiver faller ut av syne. Sist, men ikke minst er det en risiko for at bærekraftig utvikling reduseres til et slagord, eventuelt et middel for å skape sammenheng i skolefagene og motivasjon for læring, og ikke et mål i seg selv.

Begrepet dybdelcering har flere ulike betydninger og dimensjoner, og hvordan det skal forstås i NOU (2015: 8) er ikke fullstendig avklart, noe som kanskje heller ikke var hensikten. Sentrale utsagn i utredningen og stortingsmeldingen viser på den ene siden til dybden i fagene - kjerneelementer, dyp forståelse i fagene, begrepsstrukturer, big ideas, metoder og arbeidsmåter - og på den andre siden til psykologiske begreper som metakognisjon, læringsstrategier, motivasjon og overførbarhet. Det er, som denne gjennomgangen har vist, ikke åpenbart hvordan dyp læring med utgangspunkt i fagene kan føre til tverrfaglig forståelse, enn si forståelse av et sosiovitenskapelig tema som bærekraftig utvikling. I arbeidet med å oversette diskusjonen om dybdelæring fra stortingsmelding til læreplaner, vil representanter for de ulike fagene ha ulike interesser. Det å arbeide tverrfaglig med temaer vil i tillegg kunne oppleves som «truende» for enkelte fag der disse temaene ikke «naturlig» (jf. M74) - det vil si historisk - har sin tilhørighet. Bærekraftig utvikling - spesielt i en smalere forstand der folkehelse og livsmestring og demokrati og medborgerskap er utelatt - er et klart eksempel: Naturfag, og til dels samfunnsfagene har «eid» dette temaet, mens de humanistiske fagene, spesielt språkfagene ofte har blitt et slags utvendig vedheng der man «også» kan jobbe med disse spørsmålene. Samtidig er det store epistemologiske forskjeller mellom de to første, noe som kan lede til utfordrende diskusjoner i et kollegium. For å motvirke slike tendenser må de nye temaene behandles på en forpliktende måte i lærerutdanningen, og det må gis tid og rom for hele kollegiet til å arbeide med hvordan 
disse temaene kan integreres. Vi hadde også gjerne sett at de tverrfaglige temaene, her: bærekraftig utvikling, var blitt gjenstand for en litt grundigere faglig behandling i de nevnte dokumentene. For å belyse hvordan dette kan gjøres, skal vi nå gå over til å se på hvordan arbeid med bærekraftig utvikling i skolen omtales i den internasjonale ESD-litteraturen.

\section{Forholdet mellom kunnskap, holdninger og handling for bærekraftig utvikling}

Forskning understreker betydningen av at skoler har en helhetlig tilnærming til bærekraftig utvikling. I dette ligger det at innholdet i opplæringen må understøttes av de konkrete handlingene som foregår på skolen. For at teorien skal få innhold og mening for elevene, må det kort sagt være samsvar mellom teori og praksis (Gadotti, 2010; Sinnes, 2015; Sterling, 2009). Praksis i den norske skolen har, som vi har vist tidligere, i relativt liten grad oppfylt den generelle delen av læreplanens målsetning om å utvikle miljøbevisste mennesker. Arbeidet med bærekraftig utvikling i norsk sammenheng har vært knyttet til arbeid med kompetansemålene i læreplanen og i liten grad vært reflektert i skolens drift. Elevene kan for eksempel ha arbeidet med problematikk knyttet til plast i havet og samtidig opplevd at det i skolens kantine bare brukes plastbestikk; elever kan ha lært om klimautslipp og samtidig opplevd at hele lærerstaben drar på personaltur med fly til Barcelona. Ifølge klimapsykolog Per Espen Stoknes (2017) og noen av studiene han bygger sitt arbeid på, er det imidlertid ikke slik at kunnskap og holdninger mer eller mindre automatisk fører til endret atferd, men snarere omvendt. Mangelen på handlingsmuligheter, ikke dårlige holdninger eller verdier, er den største hindringen for en mer bærekraftig utvikling (Straume, 2017). Dersom man mener alvor med at skolen har bærekraftig utvikling som sin oppgave - jf. stortingsmeldingens utsagn: «Opplæringen i dette tverrfaglige temaet skal [...] bidra til at elevene lærer å tenke kritisk og handle etisk og miljøbevisst» (Kunnskapsdepartementet, 2016, s. 39) - er det gode grunner til å gå utover den kognitive forståelsen av problemene.

Videre i stortingsmeldingen står det at: «Bærekraftig utvikling handler om å ta vare på behovene til mennesker som lever i dag, uten å ødelegge fremtidige generasjoners muligheter til å dekke sine. Skal det lykkes, må det tenkes og handles lokalt, nasjonalt og globalt» (Kunnskapsdepartementet, 2016, s 39, vår utheving). Her understrekes nettopp betydningen av å handle så vel som å tenke for å lykkes med bærekraftig utvikling. Dette anerkjennes også i følgende utsagn: «Opplæringen skal bidra til at de [elevene] får tro på og anerkjenner alles ansvar for aktiv og bevisst handling for en bærekraftig utvikling». Fortsettelsen, som lyder: «En forutsetning for å kunne handle klimabevisst er kunnskap om og innsikt i klimaendringene» (s. 23) kan imidlertid peke i retning av at kunnskap er en forutsetning for handling, en antakelse som ikke er gitt (Hulme, 
2009; Norgaard, 2011; Stoknes, 2017). Vi vil i stedet trekke fram verdien av både tenkning og handling for det videre arbeidet med fornyelsen av Kunnskapsløftet. Dette er perspektiver vi finner igjen til ny overordnet del for læreplanen hvor det står: «Elevene skal få forståelse for at handlingene og valgene til den enkelte har betydning» (Kunnskapsdepartementet, 2017, s. 14). Spesielt er det viktig å tenke over at prinsippet om faglig progresjon - et tema Ludvigsenutvalget er opptatt av - også må gjelde for handlingsaspektet knyttet til dette temaet. I dagens skole blir tilnærmingen til miljøtematikk ofte mer kognitiv og teoretisk med økende alder. Her er det mulig å tenke seg at handlingene øker i kompleksitet, og utvides til å gjelde større deler av omgivelsene, når eleven beveger seg fra et skoletrinn til det neste. Eksempler på en slik progresjon kan være hvordan det jobbes helt praktisk med skolehagearbeid på barnetrinnet, som ved Brønnerud skole i Ås (Sinnes, 2015), mens det praktiske arbeidet ved Globala Gymnasiet, en stor offentlig videregående skole i Stockholm, har en mer politisk form og øver elevenes evne til å delta og påvirke politiske prosesser på en demokratisk måte. ${ }^{9}$

\section{Fra big ideas i vitenskapsfagene til samtidens store spørsmål}

Dersom det ikke gjøres en større innsats for å prioritere de spørsmålene som følger av ønsket om en mer bærekraftig utvikling, er vår gjetning, basert på historien, at fagene stort sett vil bestå som de er (om enn med noen færre kompetansemål), mens tverrfaglighet brukes for å oppfylle fagenes «sentrale» deler (Kunnskapsdepartementet, 2016, s. 38). Dette vil i praksis bety business as usual. Hvilke utfordringer gir dette? Og hvordan kunne det vært annerledes?

Ett av våre forslag er å bevege seg bort fra de store ideene, som ble unnfanget $\mathrm{i}$ en annen tid, til å se på de store spørsmålene for denne tiden. I stedet for å ta utgangspunkt i fagets bærende ideer, kunne man bruke fornyelsen av Kunnskapsløftet til å formulere spørsmål om hva det er vi lurer på, og ønsker å finne ut av, i vår egen tid. De store spørsmålene i dag kan ikke være de samme som da fagene ble til. Dersom vi tar utgangspunkt i hva vi faktisk trenger å finne ut av i dag - vår tids store spørsmål - vil dette få følger for hvordan fagene struktureres. Dette kan i sin tur knyttes til Wolfgang Klafkis poeng om at et faglig innhold, for å være «dannende», må være svar på et spørsmål. Elevene vil, med andre ord, være opptatt av hva det de skal lære, er et svar på (Klafki, 1996, s. 174). I så måte er bærekraftig utvikling et tema med stor forklaringskraft, som også gir mening til et bredt spekter av innhold - men ikke et hvilket som helst innhold. En skole som arbeider tverrfaglig med utgangspunkt i dagens store spørsmål er tidligere nevnte Globala Gymnasiet i Stockholm. Her arbeider elevene med fire langsgående, utforskende spørsmål hvert år (for eksempel: Hvordan kan Sverige bli fossilfritt innen 2050? Hvordan kan byrom gjøres bærekraftige?). Kompetansemålene som må beherskes for å kunne svare på 
disse store spørsmålene, er beskrevet for hvert tema. Fagene blir så lagt opp for å støtte elevenes læring og danne grunnlaget for å utforske spørsmålene. Den faglige kunnskapen blir altså på denne måten ikke mindre viktig, men blir satt i en meningsfull kontekst og dermed gjort relevant for elevene på en helt annen måte enn ved en tradisjonell faginndelt undervisningsform.

Å oppnå bærekraftig utvikling blir beskrevet som vår tids største utfordring (Sachs, 2015). FN-systemet anerkjente dette da de i 2015 definerte 17 bærekraftsmål som styrende for utviklingen i verden i de neste 10 årene. FNs klimapanel har gjennom sine rapporter gjort verdenssamfunnet oppmerksom på hvilke konsekvenser det vil få for miljøet på jorda dersom vi ikke lykkes med å kutte utslipp av klimagasser kraftig de neste årene (IPCC, 2014). Stockholm Resilience Center har gjennom sine modeller vist hvordan vår produksjon og vårt forbruk utarmer fosfat- og nitratreserver, forsurer havet og utrydder arter $\mathrm{i}$ et alarmerende tempo (Rockstrøm et al., 2009). Vi kjenner til plastforurensningen som er i ferd med å kvele livet i havene. Vi vet at grunnvannsreservene i verden minker. Vi kjenner til prognosene for befolkningsvekst i årene framover, og vi er klar over flyktningproblematikken som vil komme i kjølvannet av et varmere klima hvor store deler av verden vil bli ubeboelig.

Gir dagens føringer for fornyelsen av Kunnskapsløftet gode nok betingelser for at skolen skal kunne forberede elevene på å leve i denne endrede verden? Vil en fagfornyelse der «fagenes egenart» får fortsette å danne utgangspunktet for strukturene i skolen, gi det grunnlaget og redskapene elevene vil trenge for å gjennomføre den omstillingen som vil måtte komme? Som samfunnsgeografene Karen O’Brien og Elin Selboe (2015) har påpekt, endringene kommer, enten man er forberedt eller ei. Spørsmålet er derfor hvor aktiv og bevisst man skal være i disse prosessene.

Slik vi ser det, må læreplanarbeidet ta utfordringene elevene skal møte i sitt voksenliv, på alvor, og la disse utfordringene få danne grunnlaget for hvordan skolen utformes. De tre fagovergripende temaene danner etter vårt syn et godt utgangspunkt for læreplanfornyelsen. De rommer flere store spørsmål vi må finne svar på i årene framover, som: Hvordan skaffe mat og vann til en raskt voksende befolkning? Hvordan utvikle bærekraftig teknologi? Hvordan leve sammen på en fredelig og bærekraftig måte? Hvordan bevare det biologiske mangfoldet?

For at disse fagovergripende temaene skal få den plassen de fortjener, er det avgjørende at de ikke bare tas inn der de utgjør sentrale deler av det faglige innholdet, som stortingsmeldingen legger opp til, men behandles som vesentlige i seg selv. Vår gjennomgang av føringene for fornyelsen av Kunnskapsløftet viser at Ludvigsenutvalgets rapporter gir muligheter for en strukturell fornyelse. Men den viser også en reell fare for at de strukturelle endringene Ludvigsenutvalget la opp til, kan bli redusert til business as usual der tradisjonelle fagstrukturer blir førende for innholdet i fagene, og de fagene hvor det ikke er like «naturlig» å arbeide med bærekraftig utvikling, demokrati og demokrati- 
forståelse eller helse og livsmestring, fortsetter som før. Vår gjennomgang av stortingsmeldingen «Fag - Fordypning - Forståelse. En fornyelse av Kunnskapsløftet» etterlater et inntrykk av at bærekraftsproblematikken - som tidligere - rammes inn som et kognitivt spørsmål som elevene skal forstå, men uten at skolen gir tilstrekkelige redskaper til elevene for å omsette kunnskap til handling for en mer bærekraftig utvikling.

I lys av nyere forskning på utdanning for bærekraftig utvikling mener vi at fornyelsen av læreplanene må ta utgangspunkt i de store spørsmålene vi har nå, og ikke i «the big ideas» fra tiden da vitenskapsfagene ble utviklet for 200 år siden. For at skolen skal kunne bli et relevant sted for elever, må endringene i skolen stå i forhold til endringene som skjer i verden utenfor skolen. Vi mener også at skolen må ta inn over seg den psykologiske forståelsen av forholdet mellom kunnskap, holdninger og handlinger som i senere tid har fått innpass i andre sektorers miljøpolitiske forståelse, og innrette skolen slik at elevene gjennom handlingene i sin skolehverdag vil kunne høste konkrete erfaringer av hvordan bærekraftige liv kan leves.

\section{Om forfatterne}

Astrid T. Sinnes er førsteamanuensis i realfagsdidaktikk ved NMBU og har vært sentral i arbeidet med å utvikle denne lærerutdanningens fokus på bærekraftig utvikling. Hun har publisert innen feltet utdanning for bærekraftig utvikling samt kjønn og realfag i både norsk og internasjonal sammenheng. Astrid T. Sinnes er forfatter av den første norske boken om utdanning for bærekraftig utvikling rettet mot lærerutdanningen: Utdanning for bærekraftig utvikling; hva, hvorfor og hvordan? (Universitetsforlaget).

Institusjonstilhørighet: Fakultet for realfag og teknologi, Norges miljø- og biovitenskapelige universitet, Postboks 5003 NMBU, 1432 Ås

Epost: astrid.sinnes@nmbu.no

Ingerid S. Straume har doktorgrad i pedagogisk filosofi og har arbeidet med bærekraftig utvikling siden midten av 1990-tallet. Hun er ansatt ved Universitetsbiblioteket i Oslo som leder for Akademisk Skrivesenter. Straume har publisert tekster om blant annet danningsteori, miljøpolitikk, sosiale bevegelser og demokrati. Siste bok: En menneskeskapt virkelighet. Klimaendring, sosiale forestillinger og pedagogisk filosofi (Res Publica 2017).

Institusjonstilhørighet: HumSam-biblioteket, Universitetet i Oslo, Postboks 1009 Blindern, 0315 Oslo

Epost: ingerid.straume@ub.uio.no 


\section{Referanser}

Andresen, M. U., Høgmo, N. \& Sandås, A. (2015). Learning from ESD projects during the UN Decade in Norway. I R. Jucker \& R. Matar (red.), Schooling for Sustainable Development in Europe. Concepts, Policies and Educational Experiences at the End of the UN Decade of Education for Sustainable Development (s. 241-256). Dordrecht: Springer.

Bowers, C. A. (1997). The Culture of Denial: Why the environmental movement needs a strategy for reforming universities and public schools. New York: SUNY.

Brænden, M. (2008). Undervisning for bcrekraftig utvikling: finnes det en sammenheng mellom teori og praksis? En studie av hvordan naturfaglcerere på ungdomstrinnet følger opp FNs Utdanningstiår for Bcerekraftig Utvikling. Masteroppgave, Norges miljø- og biovitenskapelige universitet, Ås.

Dobson, A. (1996). Environment sustainabilities: An analysis and a typology. Environmental Politics, 5(3), 401-428.

Gadotti, M. (2010). Reorienting Education Practices towards Sustainability. Journal for Education for Sustainable Development, 4(2), 203-211.

Hulme, M. (2009) Why we disagree about climate change. Understanding controversy, inaction and opportunity. Cambridge: Cambridge University Press.

IPCC (2014). Climate Change 2014. Synthesis Report. http://www.ipcc.ch/report/ar5/syr/

Jansen, A. I. (1989). Makt og miljø. Oslo: Universitetsforlaget.

Kahn, R. (2010). Critical pedagogy, ecoliteracy, \& planetary crisis: The ecopedagogy movement. New York: Peter Lang.

Kirke- og undervisningsdepartementet (1974). Mønsterplan for grunnskolen. Oslo: Aschehoug.

Klafki, W. (1996). Kategorial dannelse. I E. L. Dale (red.), Skolens undervisning og barnets utvikling (s. 167-203). Oslo: Gyldendal.

Koller, K. T. (2009). Uteskole = praksis + teori. En studie av muligheter og utfordringer med uteskole i naturfag på videregående trinn 1. Masteroppgave, Universitetet for miljø- og biovitenskap, Ås.

KUF (1994). Naturfagutredningen. Rapport 1. Naturfag i grunnskole og lcererutdanning. Sammendrag: Funn, anbefalinger og tiltak. Oslo: Nasjonalt Læremiddelsenter. Hentet 29/6/2017 fra: http://www.nb.no/nbsok/nb/71e67a6804130481bbf3e1a17f9bff32?lang=no\#4

KUF (1996). Lœreplanverket for den 10-årige grunnskolen. Oslo: Det Kongelige Kirke-, Utdannings- og Forskningsdepartement.

Kunnskapsdepartementet (2012). Kunnskap for en felles fremtid. Revidert strategi for utdanning for bærekraftig utvikling 2012-2015. Oslo: Kunnskapsdepartementet.

Kunnskapsdepartementet (2016). Fag - Fordypning - Forståelse. En fornyelse av Kunnskapsløftet. (Meld. St. 28, 2015-2016). Oslo: Kunnskapsdepartementet. https://www.regjeringen.no/contentassets/e8e1f41732ca4a64b003fca213ae663b/no/pdfs/s tm201520160028000dddpdfs.pdf

Kunnskapsdepartementet (2017). Overordnet del - verdier og prinsipper for grunnopplæringen. Oslo: Kunnskapsdepartementet. https://www.regjeringen.no/contentassets/37f2f7e1850046a0a3f676fd45851384/overordn et-del---verdier-og-prinsipper-for-grunnopplaringen.pdf

Kvamme, O. A. (2017). Hvor ble det av humaniora? Kronikk i Dagsavisen, hentet fra http://www.dagsavisen.no/nyemeninger/hvor-ble-det-av-humaniora-1.964536

Lafferty, W. M. \& Langhelle, O. (1995). Bærekraftig utvikling. Oslo: Gyldendal.

Landfald, Ø. F. (2016). Dybdelcering. En teoretisk studie av dybdelcringsbegrepet og dets betydning for elever i skolen. Masteroppgave, Universitetet i Oslo. 
Laumann, K. (2007). The Missing Story - Education for Sustainable Development in Norway. Masteroppgave, Senter for Utvikling og miljø, Universitetet i Oslo.

Malkenes, S. (2014). Bak fasaden i Osloskolen. Oslo: Res Publica.

Mochizuki, Y. \& Yarime, M. (2016). Education for sustainable development and sustainability science: re-purposing higher education and research. I M. Barth, G. Michelsen, M. Rieckmann \& I. Thomas (red). Routledge Handbook of Higher Education for Sustainable Development (s. 11-24). Oxon: Routledge.

Naturfagsenteret (2010). Lcereplananalyse - utdanning for bcerekraftig utvikling. Hentet fra http://www.natursekken.no/c1188058/artikkel/vis.html?tid=2090227

NIFU (2012). Spørsmål til skole-Norge. Resultater og analyser fra Utdanningsdirektoratets spørreundersøkelse blant skoler og skoleeiere. Rapport 5/2012, 36-38.

NOU (2015: 8). Fremtidens skole - Fornyelse av fag og kompetanser. Hentet 7/3/2017 fra https://www.regjeringen.no/contentassets/da148fec8c4a4ab88daa8b677a700292/no/pdfs/ nou201520150008000dddpdfs.pdf.

Norgaard, K. M. (2011). Living in denial. Boston, Mass: MIT press.

O'Brien, K. \& Selboe, E. (red.) (2015). The adaptive challenge of climate change. Cambridge: Cambridge University Press.

Rockstrøm, S. et al. (2009). A safe operating space for humanity, Nature (461), 472-475.

Raabs, N. K. (2010). No Child in the Norwegian Woods: A study on Education for Sustainable Development in Norwegian Primary Schooling. Masteroppgave, Universitetet i Oslo.

Sachs, J. (2015). The Age of Sustainable Development. New York: Columbia University Press.

Sandås, A. \& Isnes, A. (2015). Bærekraftig utvikling. Kimen (1). Oslo: Naturfagsenteret. Hentet 7/3/2017 fra http://www.naturfagsenteret.no/c1520014/binfil/download2.php?tid=2124018

Scott, W. (2013). Developing the sustainable school: thinking the issues through. Curriculum Journal, 24(2), 181-205.

Sinnes, A. (2015). Utdanning for bœrekraftig utvikling. Hva, hvorfor og hvordan? Oslo: Universitetsforlaget.

Sinnes, A. \& Eriksen, C. (2016). Education for Sustainable Development and International Student Assessments: Governing Education in Times of Climate Change. Global Policy, $7(1), 46-55$.

Sinnes, A. \& Jegstad, K. (2011). Utdanning for Bærekraftig Utvikling: To unge realfagslæreres møte med skolehverdagen. Norsk pedagogisk tidsskrift, 04, 248-259.

Sjøberg, S. (2015). PISA and Global Educational Governance - A Critique of the Project, its Uses and Implications. Eurasia Journal of Mathematics, Science \& Technology Education, 11(1), 111-127.

Sjaastad, J., Carlsten, T. C., Opheim, V. \& Jensen, F. (2014). Evaluering av Den naturlige skolesekken: Utdanning for bærekraftig utvikling på ulike lcringsarenaer. NIFU-Rapport 38/2014. Oslo: Nordisk institutt for studier av innovasjon, forskning og utdanning. https://brage.bibsys.no/xmlui/bitstream/handle/11250/280354/NIFUrapport201438.pdf? sequence $=5$ \&isAllowed $=y$

Sterling, S. (2009). Sustainable Education. Re-Visioning Learning and Change, Totnes, UK: Green Books.

Stoknes, P. E. (2017). Det vi tenker på når vi prøver å ikke tenke på global oppvarming. Oslo: Tiden.

Straume, I. S. (2005). Depoliticizing environmental politics: Sustainable development in Norway. I R. Paehlke \& D. Torgerson (red.), Managing Leviathan. Environmental politics and the administrative state (s. 191-207). Peterborough, Ontario: Broadview. 
Straume, I. S. (2016). «Norge ligger på dette området langt fremme i forhold til de fleste land»: Utdanning for bærekraftig utvikling i Norge og Sverige. Nordisk tidsskrift for pedagogikk og kritikk, 2(3), 78-96.

Straume, I. S. (2017). En menneskeskapt virkelighet. Klimaendring, sosiale forestillinger og pedagogisk filosofi. Oslo: Res Publica.

Sundstrøm, E. (2016). Utdanning for bcerekraftig utvikling (UBU) fra et lcererperspektiv. En studie av naturfaglereres perspektiv og undervisningspraksis av UBU. Masteroppgave, Norges Arktiske Universitet, Tromsø.

Sæther, A. K. (2017). De beste intensjoner: oljelandet i klimakampen. Oslo: Cappelen Damm. UNESCO (2006). Framework for the UN DESD Implementation Scheme. Hentet 7/3/2017 fra http://unesdoc.unesco.org/images/0014/001486/148650E.pdf

Utdanningsdirektoratet (2011). Generell del av læreplanen. Hentet 7/3/2017 fra https://www.udir.no/upload/larerplaner/generell_del/generell_del_lareplanen_bm.pdf

Verdenskommisjonen for miljø og utvikling (1987). Vår felles framtid. Oslo: Tiden Norsk Forlag.

Wals, A. E. (2012). Learning Our Way Out of Unsustainability: The Role of Environmental Education. I S. Clayton (red.), The Oxford Handbook of Environmental and Conservation Psychology (s. 628-644). Oxford: UP.

Wolla, I. Aa. (2015). Utdanning for bœrekraftig utvikling i norsk skole - En todelt kvantitativ undersøkelse om ungdomsskoleelever og deres naturfaglærere. Masteroppgave, Høgskolen i Oslo og Akershus, Oslo.

\footnotetext{
${ }^{1}$ Dette gjelder ikke bare for Norge, men også for eksempel USA (Kahn, 2010).

${ }^{2}$ For en grundig diskusjon av klimaendring som tema i skolen, se Straume (2017).

${ }^{3}$ Rettere sagt, i småskolen het faget Natur, samfunn og miljø (NaSaMi), og på mellomtrinnet Natur- og miljøfag og Samfunnsfag.

${ }^{4}$ Kristendom, religion, livssyn og etikk. Faget har hatt ulike navn i perioden, der både K og E har vært ute av navnet.

${ }^{5}$ Dette er også bakgrunnen for at studenter lettere har funnet informanter i Steinerskolene enn i den offentlige skolen (se for eksempel Raabs, 2010).

${ }^{6}$ For en sammenligning mellom Norges og Sveriges satsninger på utdanning for bærekraftig utvikling, se Straume (2016).

${ }^{7}$ Ørjan Landfald har skrevet masteroppgave om dybdelæring med Sten Ludvigsen (leder av Ludvigsenutvalget) som veileder.

${ }^{8}$ Arbeidet med å definere kjerneelementer i de ulike fag bør ifølge departementet foregå med representanter for ulike grupper, og nevner «representanter for UH-sektoren og lærerprofesjonen» (Kunnskapsdepartementet, 2016, s. 36).

${ }^{9}$ For mer informasjon om Globala Gymnasiet, se http://globalagymnasiet.stockholm.se/
} 